\title{
DESIGN PRINCIPLES OF THE HOSPITAL CLEAN ROOMS
}

\begin{abstract}
Summary
Clean rooms can be defined as areas that are specifically controlled for particulate and microbial contamination and where they are constructed and used to reduce the number of infectious disease agents settling and multiplying and accessing from outside.

In this study, the design and implementation of the air conditioning system in accordance with international standards, in particular DIN 1946-4, has been explained for an operating room in hospitals which is in the clean room and has the highest risk of infection. The tasks of physicians, engineers and architects in operating room design were mentioned and finally the cleaning, testing, adjustment and balancing (TAB) and validation process of the air conditioning system were mentioned.

In particular, the risks of infections that may arise during the surgical intervention in the operating room and its relation to the air conditioning system have been mentioned and it has been emphasized that the biggest responsibility for hospital infections falls to engineers and architects, especially doctors and medical staff.
\end{abstract}

Key words: $\quad$ Clean room, operating room, air conditioning, testing, adjusting, balancing, DIN 1946-4

\section{Introduction}

Hospitals have a lot of sterile volume with high risk for infection. Air conditioning and ventilation systems play an important role in the risk of infection in these sterile volumes. In non-hygienic environments, infection is transmitted from one location to another in a variety of ways. Airborne infection transmission between infection transmission routes is closely related to the mechanical engineers working in the air conditioning and ventilation sector.

The hygienic nature of the hospital air is of great importance to the patient and hospital team health. In the study conducted within the scope of this article, the design and implementation of the conditioning system of operating rooms with the highest prevalence in terms of risk of infection from hospital clean rooms has been described [1]. During surgery, the infectious pollution can be carried to the surgical site in two ways. These can be direct contact and airborne transport. This transfer may also result in infection of the surgical site, which may result in failure of the operation, re-surgical intervention, prolongation of the treatment, or even loss of the patient's life due to the operation. 
Doctor Charnley who was a surgeon at the Wrightington Hospital in Wigan, England in the early 1960s saw that although he was a good doctor, $9 \%$ of his patients died from the infection they received during surgery. This situation made his very uncomfortable and produced a solution for this. In the report prepared by Doctor Charnley in 1969, he found that the infections transmitted in her hip bone operations decreased from $9 \%$ to $1 \%$ by using ceiling and protective clothes with laminar flow. Dr. Charnley's finding a miraculous solution led to the project which he conducted with Hug Howard who was clean room manufacturer. Thus, in this field, they first developed a system called Green House and patented by them [2].

In Europe, the rate of post-operative contamination was $0.3 \%$ in hospitals and the mortality rate decreased to $0.15 \%$ with the correction activities performed. As a result of a British - Scandinavian study conducted in 19 hospitals for 5 years, hip bone and knee cap surgeries, it was found that the rate of infection was $4.5 \%$ when the number of particles in $1 \mathrm{~m}^{3}$ air was 400 , and the rate of particle was reduced to 20 by $1.5 \%$ [3].

In the United States, it has been reported that hospital infections has developed at 2 million people annually, and the cost is around $\$ 5$ billion. Within the scope of these infections, it has been determined that 106.000 people die annually, $70 \%$ of infections develop with resistant pathogens and with this the cost and mortality increase even more. Similarly, according to the UK National Health (NHS) data, it has been explained that both patients suffered from hospital infections and this situation costed a billion British pounds. [4]. Studies carried out by experts and organizations during the last 50 years clearly reveal that hospital infections and infections that may occur during/after surgery and air conditioning systems in hospitals have a direct effect on human health.

In this study, first put into service in 1987 and until today for Istanbul Kartal Lutfi Kirdar Training and Research Hospital in Turkey, which continues to be used in a variety of revisions, has been designed, manufactured and put into practice by testing, datas of a hygienic air handling unit have been presented. The hospital clean rooms have been designed to provide uninterrupted service in the event of an earthquake with its compliance with international standards in terms of hygiene and air conditioning. In order to set an example, the process required for the test $\&$ commissioning process related to the commissioning of the air conditioning system manufactured in accordance with the design of an operating room in the hospital has been explained. Previous experiences and proposals of the Republic of Turkey Ministry of Health with international standards in the realization of the project has been taken into consideration.

\section{International standards}

There are three parameters that must be checked in the air conditioning and ventilation applications. These; temperature, humidity, and air change coefficient. In air conditioning systems designed for hygienic environments, in addition to these parameters, the number of airborne particles and microorganisms, air velocity, air distribution, and the pressure relationship between the hygienic area and the surrounding areas must be kept within the specified range of values. The range of values required by these parameters has been described in hospital ventilation standards used in many countries around the world $[5,6]$.

\subsection{Hospital clean rooms parameters value range according to international standards}

A summary of design parameters for hospital clean rooms according to international standards is given in comparative Table 1 [5]. In addition to the standards set out in Table 1, 
The Guidelines of various health organizations, depending on the specifications and the purpose of the cleanroom user, can be used in the criteria set out by the World Health Organization (WHO). Besides these standards, ventilation duct manufacturing, duct leakage tests, duct cleaning, test adjustment balancing (tab), fire and smoke control, particle count and hygienic air conditioning system equipment; SMACNA, DW-144, Eurovent, NADCA, AMCA, NEBB, NFPA and EN standards are also utilized [7]. The project, design and applications related to hygienic environments in Turkey are based on the standards of DIN 1946-4 and ASHRAE-170 [8,9,10,12]. However, Republic of Turkey Minimal Design Guide to the Ministry of Health must be taken into account [12]. The design parameters mentioned can be examined in general by engineering and medical aspects as follows. In addition to these standards, FGI (The Facility Guidelines Institute) guidelines have also been used for comparison purposes.

Table 1 Comparison of design parameters according to international standards

\begin{tabular}{|c|c|c|c|c|c|c|c|c|c|c|}
\hline Standard & \begin{tabular}{|c} 
Operating \\
Room \\
Type
\end{tabular} & $\begin{array}{l}\text { Temp. } \\
\left({ }^{\circ} \mathrm{C}\right)\end{array}$ & $\begin{array}{c}\text { Humidity } \\
\text { (\%) }\end{array}$ & Filter & $\begin{array}{c}\text { Velocity } \\
(\mathrm{m} / \mathrm{s})\end{array}$ & $\underset{\text { Distribution }}{\text { Air }}$ & Pressure & $\Delta \mathbf{P}$ & $\begin{array}{c}\text { Air } \\
\text { Change } \\
\text { Number }\end{array}$ & $\begin{array}{c}\text { Total } \\
\text { Air } \\
\text { Change } \\
\text { Number }\end{array}$ \\
\hline \multirow{3}{*}{ ASHRAE } & Class A & \multirow{3}{*}{$18-26$} & \multirow{3}{*}{$30-60$} & - & \multirow{3}{*}{$0.25-0.45$} & \multirow{3}{*}{$\begin{array}{l}\text { Laminar / } \\
\text { Verticle }\end{array}$} & \multirow{3}{*}{$\mathrm{P}(+)$} & \multirow{3}{*}{$\begin{array}{l}2.5-7.5 \mathrm{~Pa} \\
35-47 \mathrm{~L} / \mathrm{s}\end{array}$} & \multirow{3}{*}{$\begin{array}{c}5^{*} / 15^{* *} \\
15(\mathrm{lt} / \mathrm{s}) / \mathrm{kişi}\end{array}$} & \multirow{3}{*}{$\begin{array}{l}25^{*}- \\
15^{* *}\end{array}$} \\
\hline & Class B & & & - & & & & & & \\
\hline & Class C & & & - & & & & & & \\
\hline \multirow{3}{*}{ AIA } & Class A & \multirow{3}{*}{$20-23$} & \multirow{3}{*}{$30-60$} & - & \multirow{3}{*}{ - } & \multirow{3}{*}{$\begin{array}{l}\text { Laminar / } \\
\text { Verticle }\end{array}$} & \multirow{3}{*}{$\mathrm{P}(+)$} & \multirow{3}{*}{$2.5 \mathrm{~Pa}$} & \multirow{3}{*}{3} & \multirow{3}{*}{15} \\
\hline & Class B & & & - & & & & & & \\
\hline & Class C & & & - & & & & & & \\
\hline \multirow{2}{*}{ DIN } & Class 1a & \multirow{2}{*}{$19-26$} & \multirow{2}{*}{$30-60$} & G4-F7-F9-H13 & \multirow[b]{2}{*}{ - } & \multirow{2}{*}{$\begin{array}{c}\text { Laminar/Vertic } \\
\text { le/ Mixed Air }\end{array}$} & \multirow{2}{*}{$\mathrm{P}(+)$} & \multirow{2}{*}{$20 \mathrm{~m}^{3} / \mathrm{m}$} & \multirow{2}{*}{$\begin{array}{c}800-1200 \\
\mathrm{~m}^{3} / \mathrm{h}\end{array}$} & \multirow[b]{2}{*}{ - } \\
\hline & Class $1 \mathrm{~b}$ & & & G4-F7-F9 & & & & & & \\
\hline $\mathrm{CBZ}$ & - & $18-24$ & - & F5-F7-F9-H13 & - & $\begin{array}{l}\text { Laminar/ } \\
\text { Verticle }\end{array}$ & $\mathrm{P}(+)$ & - & - & - \\
\hline \multirow{2}{*}{ VDI } & Class 1a & \multirow{2}{*}{$18-24$} & \multirow{2}{*}{$30-50$} & \multirow{2}{*}{ F5-F7-F9-H13 } & \multirow{2}{*}{$0.20-0.30$} & \multirow{2}{*}{$\begin{array}{c}\text { Laminar/Vertic } \\
\text { le/ Mixed Air }\end{array}$} & \multirow{2}{*}{$\mathrm{P}(+)$} & $20 \mathrm{~m}^{3} / \mathrm{m}$ & $800-1200$ & 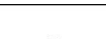 \\
\hline & Class $1 \mathrm{~b}$ & & & & & & & $20 \mathrm{~m}^{3} / \mathrm{m}$ & $\mathrm{m}^{3} / \mathrm{h}$ & - \\
\hline NPP & General & $19-24$ & 45,60 & G2-F2-A3 & 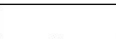 & 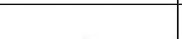 & D & 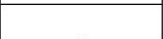 & 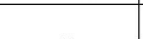 & \\
\hline NBR & Cesarean & $22-26$ & $45-60$ & - & - & - & $\mathrm{P}(+)$ & - & - & - \\
\hline CDC & - & - & $30-60$ & - & - & - & $\mathrm{P}(+)$ & - & 3 & 15 \\
\hline HICPAC & - & - & $30-60$ & - & - & - & $\mathrm{P}(+)$ & - & 3 & 15 \\
\hline & Risk-3 & $19-26^{1}$ & 60 & $C$ & 025 & Laminar/ & D & & 6 & \\
\hline NF S90 & Risk-4 & $15-30^{2}$ & $40-60$ & 114 & $0.25-0.35$ & Verticle & $\mathrm{P}(+)$ & $15 \mathrm{~Pa}( \pm 5 \mathrm{~Pa})$ & 6 & - \\
\hline $\begin{array}{c}\text { UNE } \\
100713\end{array}$ & - & - & - & $\begin{array}{c}\text { F6-F9-H13 } \\
\text { (H14) }\end{array}$ & - & $\begin{array}{c}\text { Laminar / } \\
\text { Verticle }\end{array}$ & $\mathrm{P}(+)$ & - & - & - \\
\hline & $\begin{array}{l}\text { ecommende } \\
* \text { Total reco }\end{array}$ & $\begin{array}{l}\text { Gresh and } \\
\text { nended } n\end{array}$ & $\begin{array}{l}\text { tal air exch } \\
\text { mber of air }\end{array}$ & $\begin{array}{l}\text { ange numbers for } \\
\text { hanges for } 100 \%\end{array}$ & $\begin{array}{l}\text { mixing air } \\
\text { fresh air } \mathrm{s}\end{array}$ & $\begin{array}{l}\text { ystems } \\
\text { tems }\end{array}$ & 2. No sur & $\begin{array}{l}\text { 1. Operating roc } \\
\text { gical interventio }\end{array}$ & $\begin{array}{l}m \text { at full load } \\
n \text { in the operat }\end{array}$ & ing room \\
\hline
\end{tabular}

Pressurization. The criteria for determining zones of different pressure, air flow between rooms "for hygienic reasons alone high grade conditions require non-microorganism from the room, the normal rooms might be true non-microorganism circumstances require," departing from the general principle, according to the direction of air flow from clean areas positive $(+)$, neutral in less polluted areas $( \pm)$, very dirty in areas $(-)$ to the negative pressure zones are created. Pressurization for the operating room should be in the septic operating room with neutral $( \pm)$ or in the case of excessive infectious cases negative (-), and in the aseptic operating rooms positive $(+)$ pressure zones.

Temperature. The temperature of the operation room is of great importance to the comfort of the surgical team. The temperature is different from those who are dressed in protective clothing, who operate under a certain physical activity and who are working under high temperature Operating lights and nurses who are not working as hard as surgeons during the surgery or the anesthesia specialists feel comfortable. The temperature is determined according to the type of surgery and the comfort of the surgical team. Usually heart surgery starts at $15-16{ }^{\circ} \mathrm{C}$. During surgery, the temperature of the room is raised to $26{ }^{\circ} \mathrm{C}$. For organ 
transplants, the operating room temperature is usually $15-16{ }^{\circ} \mathrm{C}$. However, in pediatric surgeries, the temperature of the operating room should be around $30{ }^{\circ} \mathrm{C}$. The reason for this is that children are more easily affected than low temperatures compared to adults. It is important to note here that the prevention of hypothermia by the patient for both children and adults. Previous studies have shown that the patient's heat loss is high at the operating room temperatures below $21^{\circ} \mathrm{C}$ and the risk of entering hypothermia is increased.

Relative humidity - static electricity relationship. Surgically, the relative humidity is an important factor in the operation of the wound in the operating area and blood coagulation. Conditions in which high relative humidity rates are requested in the operation rooms, such as eye operations or tissue transplants for burn treatment, are not desirable in the operation area. In cases where the relative humidity drops below 35\% in terms of Engineering, static electricity loads begin to increase. Considering that there are many electrical devices in the operating room, relative humidity control is important. In addition, as mentioned in NFPA 996 , it is requested that the relative humidity value should be at least $35 \%$ in the areas where anesthesia gases are used, in order not to cause a fire caused by static electricity loads. In clean room applications where the relative humidity is below $35 \%$, grounding can be done in mechanical installations independent of building grounding.

Air distribution and air velocity. Air velocity is an important factor when considering surgery as it causes dryness in the operating area. In engineering air velocity is the parameter that determines the type of flow laminar or turbulent. Surgery rooms are examined according to air distribution and two different types are encountered, these are laminar air flow and turbulence air flow rooms.

Number of particles and microorganisms. Particles in the air are micro-organism carriers. Therefore, the number of particles in the air and the risk of infection in the surgical site are directly proportional. To reduce this risk, the air needs to be filtered.

\subsection{Classification of hospitals according to DIN-1946 standard}

DIN 1946 standard, high and very high hygiene rooms are given, Class I, normal level of hygiene rooms are divided into Classes II. The operating room is a room for surgical intervention between Class-I volumes that requires very high hygiene. Since operating rooms require different techniques and applications in terms of air conditioning and ventilation, the hospital sterile volumes are divided into two groups; Class-Ia and Class-Ib.

\section{A sample operatıng room design for hospital clean rooms}

The operating room has a usage area of about $40 \mathrm{~m}^{2}$ and a net floor height of $3 \mathrm{~m}$ between the floor and ceiling. In the operating room, one for patient access and the other for the use of the surgical team, during the surgical intervention equipment, drugs, materials, etc. there are two doors left for shipment. The operating room is designed to be an intervention room for risky and long-term surgical operations in Class 1a according to DIN 1946-4. The dimensions of the laminar flow ceiling were $(3.2 \mathrm{~m}) \times(3.2 \mathrm{~m})$. In this way, a laminar and/or low turbulence flow has been formed on the patient at the surgical table during the surgical intervention. With this, particle concentration is provided to be minimum. The fiber holder suction grilles are positioned symmetrically to the four corners of the operating theater. 


\subsection{Operating room mechanical installation}

Operating room air conditioning system is designed as a single system to air conditioning a hygienic air conditioning unit. As the plant feeds the single operating room, $35 \%$ fresh air is selected in mixture, so that the air to be absorbed from the outside environment is more clean and in better conditions than the air that comes from the exhaust conditioned, filtered and heated/cooled return air is re-used to save energy. In the duct system, stainless pipes are preferred to avoid corrosion, while self-flanged ducts are used to minimize air leaks. Hygienic air handling unit is positioned close to the operating room in order to minimize pressure loss. The hot water needed by the heater battery of the hygienic air handling unit is provided through the boilers. The cold water needed by the cooler battery is supplied by the chillers. In the heating system, $70{ }^{\circ} \mathrm{C} / 50{ }^{\circ} \mathrm{C}$ for the hot water regime and $6{ }^{\circ} \mathrm{C} / 11^{\circ} \mathrm{C}$ for the cooling system. In order to meet the sudden flow changes in the duct system and to maintain the positive pressure balance of the operating room, the VAV box and the duct type electric heater were used to cover the muffler and the sudden temperature changes.

\subsection{Operating room duct design and calculation}

Hygienic air handling unit blowing and exhaust air flows were determined for the operating room in Class-1a using a ceiling with a flow rate of $0.22 \mathrm{~m} / \mathrm{s}$.

- Supply air flow $=(3.2 \mathrm{~m}) \times(3.2 \mathrm{~m}) \times(0.22 \mathrm{~m} / \mathrm{s}) \times(3600)=8110 \mathrm{~m}^{3} / \mathrm{h} \rightarrow$ nearly $10 \%$ safety $8800 \mathrm{~m}^{3} / \mathrm{h}$

- Exhaust air flow $=7000 \mathrm{~m}^{3} / \mathrm{h} \rightarrow 10 \%$ safety $7700 \mathrm{~m}^{3} / \mathrm{h}$

When performing tests related to air flow detection, calculated flow values have been selected to provide $110 \%$ flow rate, which is a value above the minimum air cycle numbers according to ASHRAE. The ventilation ducts of the operating room are shown in Figure 1. The exhaust ducts and their units are shown in Figure 2.

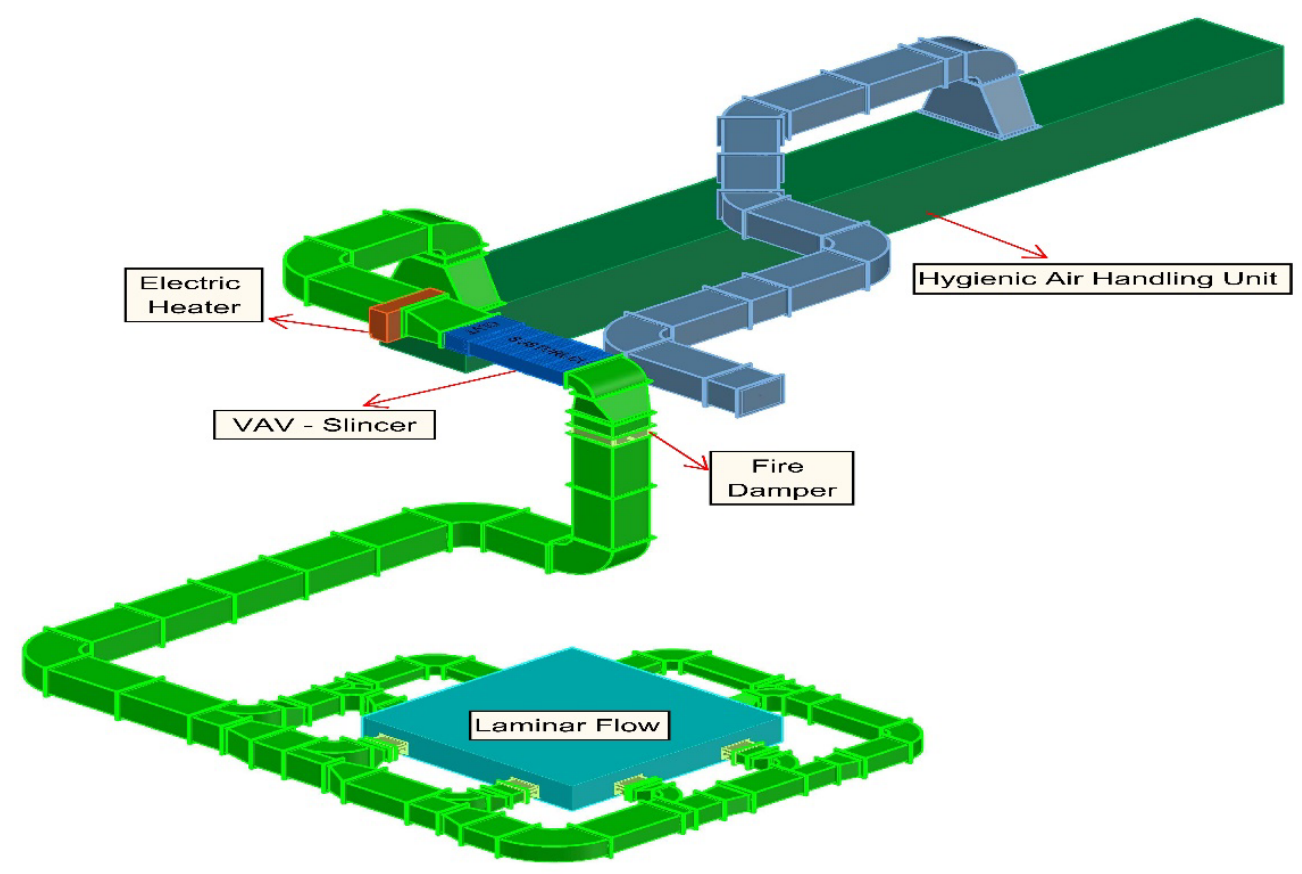

Fig. 1 Operating room supply ducts 


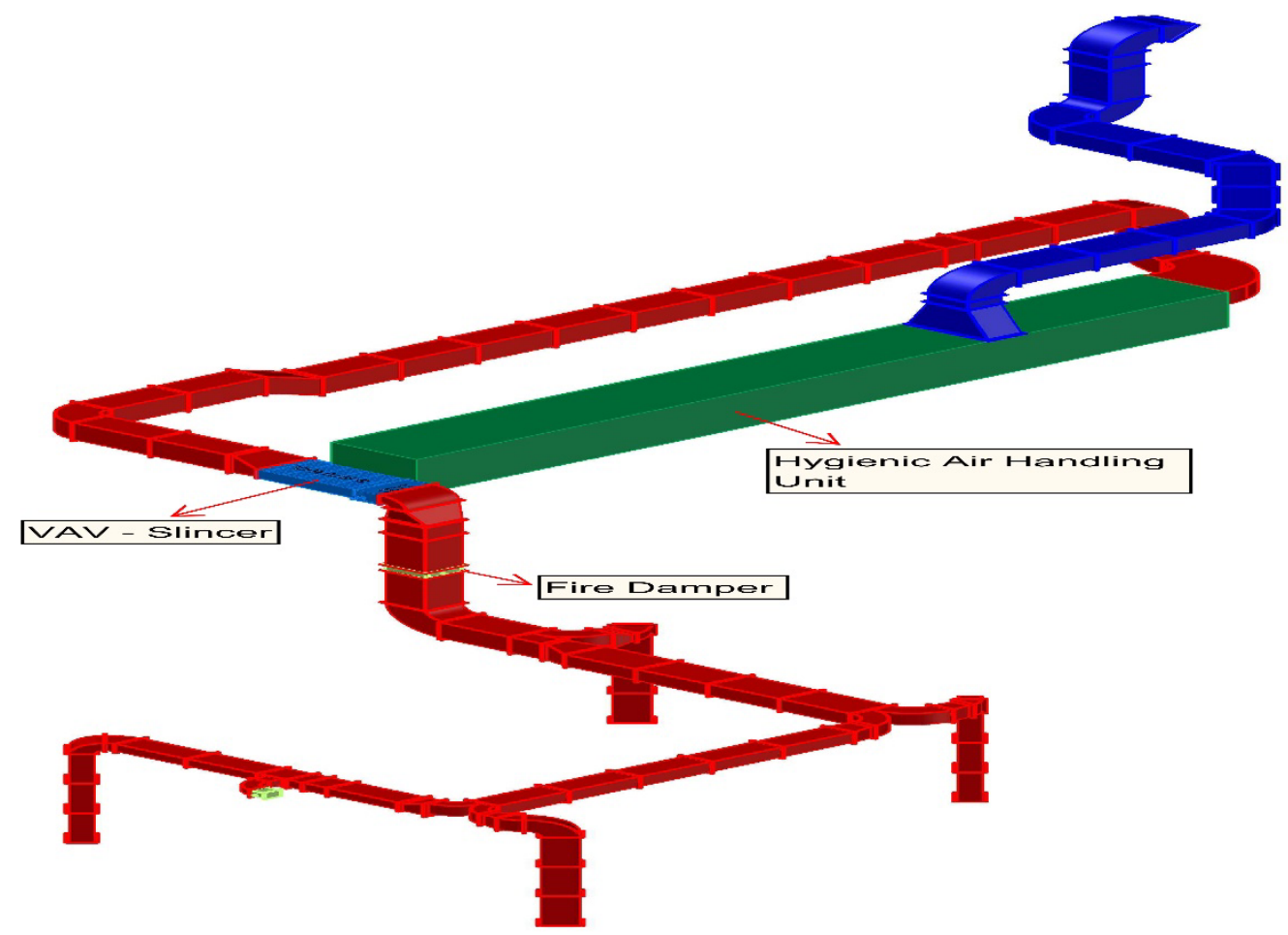

Fig. 2 The operating room exhaust ducts

3.3 Hygienic air handling unit and equipment account

Hygienic air handling units and units are shown schematically in Figure 3.

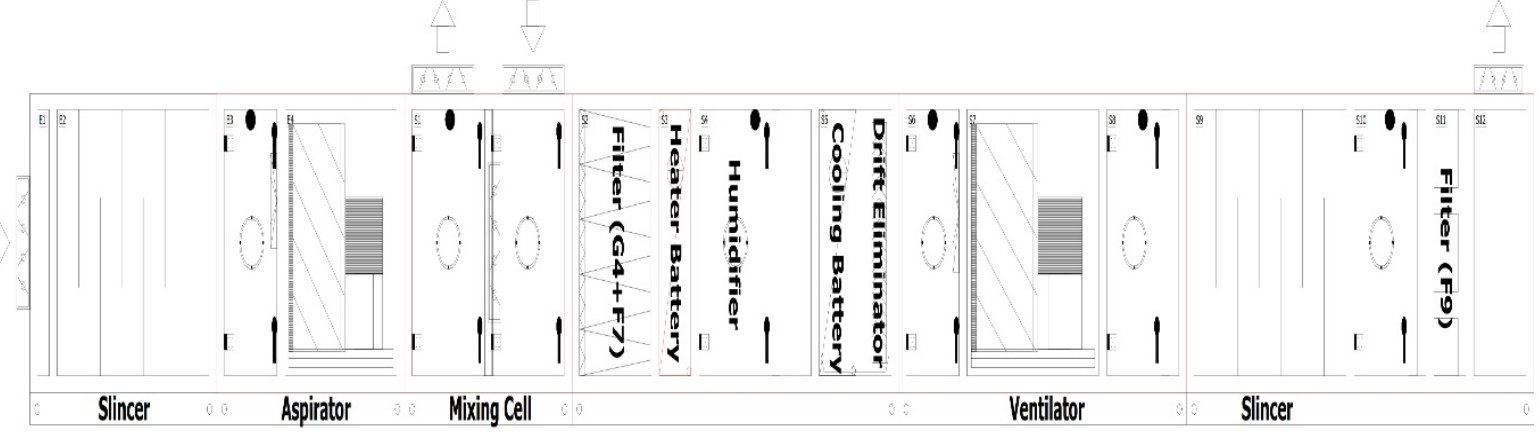

Fig. 3 Hygienic air handling units schematic display

The pressure losses of the units on the ventilator (supply) and aspirator (exhaust) lines of hygienic air conditioning plant were taken from the manufacturer's catalogue and for supply $160 \mathrm{mmWC}$, for exhaust $60 \mathrm{mmWC}$ determined.

Filtering. Filtration according to DIN1946-4, in 4 stages, G4 and F7 in fresh air inlet, respectively, and F9 in the power outlet using the filter from large-size particles in the air to small-size particles were filtered. In the ceiling with laminar flow where the air was blown into the operating room, $0.3 \mu \mathrm{m}$ and smaller particles were filtered using HEPA (H-14).

Supply and exhaust fans account and selection. Since the supply and exhaust flow rates are different for the hygienic air handling unit, both individual fan calculations and selections have been made. Plug type fan is preferred as fan. The lack of belt-pulley mechanism in plug fans prevents the accumulation of microorganisms in the ventilator section and provides great convenience in cleaning and disinfection of the inside of the device. In addition, the system 
does not have to be stopped to replace the belt pulley. During the operation, there are no problems such as the belt breaking. Fans in HVAC systems are divided into two as radial and axial fans. Plug type fan is in the axial fan group to be used in the air conditioning plant. Axial fans provide the entire pressure by taking advantage of the speed to turn into static pressure. They don't take advantage of centrifugal forces. Therefore, the total static pressure in these fans is equal to the total pressure. Fan power is calculated by taking into account the efficiency with air flow and total pressure loss.

$$
N_{\mathrm{L}}=\frac{\dot{v} \cdot \Delta P_{\mathrm{t}}}{3600 \cdot \eta_{\mathrm{L}}}
$$

In this equation, $N_{\mathrm{L}}$ is fan power (Watt), $\dot{v}$ air flow rate $\left(\mathrm{m}^{3} / \mathrm{h}\right), \Delta P_{\mathrm{t}}$ is total pressure loss $(\mathrm{Pa})$, and $\eta_{\mathrm{L}}$ is the fan efficiency. Plug type fans, such as the fan and the motor is directly coupled systems power factor 1.1 is taken. A safety margin of between $10 \%$ and $20 \%$ is added for possible pressure and flow losses in the calculations. In cases where the operating room is not used for both fans, the system is operated with half flow rate and frequency converter is selected to reduce energy consumption. The characteristics of fans and electric motors selected from the catalogues of fan and electric motor manufacturers as a result of calculations for ventilators and aspirators are given in Table 2.

Table 2 Ventilator and aspirator characteristics

\begin{tabular}{|l|l|l|l|l|l|l|l|}
\hline \multicolumn{3}{|c|}{ Ventilator } & \multicolumn{4}{c|}{ Aspirator } \\
\hline Flow & $8800 \mathrm{~m}^{3} / \mathrm{h}$ & Efficiency / IP & IE2 / IP55 & Flow & $7700 \mathrm{~m}^{3} / \mathrm{h}$ & Efficiency / IP & IE2 / IP55 \\
\hline Diameter & $450 \mathrm{~mm}$ & Current / Voltage & $20 \mathrm{~A} / 400 \mathrm{~V}$ & Diameter & $400 \mathrm{~mm}$ & Current / Voltage & $20 \mathrm{~A} / 400 \mathrm{~V}$ \\
\hline Efficiency & $73 \%$ & Efficiency & $89 \%(2 \mathrm{pole})$ & Efficiency & $55 \%$ & Efficiency & $85 \%(2 \mathrm{pole})$ \\
\hline Power & $5.2 \mathrm{~kW}$ & Nominal power & $11 \mathrm{~kW}$ & Power & $2.28 \mathrm{~kW}$ & Nominal power & $3 \mathrm{~kW}$ \\
\hline Revolution & $2450 \mathrm{rpm}$ & Engine speed & $2955 \mathrm{rpm}$ & Revolution & $2514 \mathrm{rpm}$ & Engine speed & $2885 \mathrm{rpm}$ \\
\hline
\end{tabular}

Calculation of mixture air flow and temperature. The air handling unit was selected as a mixture air (fresh air) by $35 \%$. Accordingly, the required fresh air flow, mixture air flow and exhaust air flow are calculated.

- $\quad$ Required fresh air flow $=\left(8800 \mathrm{~m}^{3} / \mathrm{h}\right) \times(0.35)=3080 \mathrm{~m}^{3} / \mathrm{h}$

- Return air flow in the mixing room $=\left(8800 \mathrm{~m}^{3} / \mathrm{h}\right)-\left(3080 \mathrm{~m}^{3} / \mathrm{h}\right)=5720 \mathrm{~m}^{3} / \mathrm{h}$

- Exhaust air flow $=\left(7700 \mathrm{~m}^{3} / \mathrm{h}\right)-\left(5720 \mathrm{~m}^{3} / \mathrm{h}\right)=1980 \mathrm{~m}^{3} / \mathrm{h}$

The external environment and internal volume conditions determined from the psychrometric diagram for summer and winter months are given in Table 3 for summer and Table 4 for winter months. According to the external environment and internal volume conditions, the mixture air temperature in summer and winter months can be calculated from the equation.

Table 3 Psychrometric properties of air for summer months

\begin{tabular}{|l|c|c|}
\hline & $\begin{array}{c}\text { Outdoor } \\
\text { Conditions }\end{array}$ & $\begin{array}{c}\text { Indoor } \\
\text { Conditions }\end{array}$ \\
\hline Dry bulb tem. $\left({ }^{\circ} \mathrm{C}\right)$ & 33 & 24 \\
\hline Wet bulb tem. $\left({ }^{\circ} \mathrm{C}\right)$ & 24.5 & 17.1 \\
\hline Relative humidity $(\%)$ & 50 & 50 \\
\hline Dew point tem. $\left({ }^{\circ} \mathrm{C}\right)$ & 21.2 & 13 \\
\hline Enthalpy $(\mathrm{kJ} / \mathrm{kg})$ & 73.8 & 47.8 \\
\hline Specific hum. $(\mathrm{g} / \mathrm{kg})$ & 15.8 & 9.3 \\
\hline
\end{tabular}

Table 4 Psychrometric properties of air for winter months

\begin{tabular}{|l|c|c|}
\hline & $\begin{array}{c}\text { Outdoor } \\
\text { Conditions }\end{array}$ & $\begin{array}{c}\text { Indoor } \\
\text { Conditions }\end{array}$ \\
\hline Dry bulb tem. $\left({ }^{\circ} \mathrm{C}\right)$ & -3 & 22 \\
\hline Wet bulb tem. $\left({ }^{\circ} \mathrm{C}\right)$ & -3.5 & 15.4 \\
\hline Relative humidity $(\%)$ & 90 & 50 \\
\hline Dew point tem. $\left({ }^{\circ} \mathrm{C}\right)$ & -4.2 & 11.1 \\
\hline Enthalpy $(\mathrm{kJ} / \mathrm{kg})$ & 3.6 & 43 \\
\hline Specific hum. $(\mathrm{g} / \mathrm{kg})$ & 2.6 & 8.2 \\
\hline
\end{tabular}




$$
T_{\mathrm{M}}=\frac{\left(\dot{m}_{0} \cdot T_{0 \mathrm{~d}}\right)+\left(\dot{m}_{\mathrm{E}} \cdot T_{\mathrm{Id}}\right)}{\dot{m}_{0}+\dot{m}_{\mathrm{E}}}
$$

$T_{\text {Msummer }}=27.15{ }^{\circ} \mathrm{C}$ and $T_{\text {Mwinter }}=13.3{ }^{\circ} \mathrm{C}$ external environmental conditions psychrometric diagram for $\mathrm{P} 1, \mathrm{P} 2$ and $\mathrm{P} 3$ can be pointed from psychometric processes,

For summer conditions;

- Relative humidity; $\phi=50 \%$

- Wet bulb temperature; $T_{\mathrm{Ms}}=19.5^{\circ} \mathrm{C}$

- Dew point temperature; $T_{\mathrm{Mdp}}=15.8^{\circ} \mathrm{C}$

- Enthalpy; $h_{\mathrm{M}}=56.1 \mathrm{~kJ} / \mathrm{kg}$

- Specific humidity; $W=11.2 \mathrm{~g} / \mathrm{kg}$
For winter conditions;

- Relative humidity; $\phi=55 \%$

- Wet bulb temperature; $T_{\mathrm{Mw}}=8.8^{\circ} \mathrm{C}$

- Dew point temperature; $T_{\mathrm{Mdp}}=4.5^{\circ} \mathrm{C}$

- Enthalpy; $h_{\mathrm{K}}=26.6 \mathrm{~kJ} / \mathrm{kg}$

- Specific humidity; $W=5.2 \mathrm{~g} / \mathrm{kg}$

Heater capacity account. The heater capacity is calculated by considering inlet and outlet temperatures with air flow.

$$
Q_{\text {Heating }}=\dot{m}_{\mathrm{T}} \cdot\left(h_{\mathrm{Ih}}-h_{0 \mathrm{~h}}\right)(\mathrm{kW})
$$

The temperature of the mixture air entering the heater was $13.3^{\circ} \mathrm{C}$, The relative humidity was $55 \%$ and the specific enthalpy was $26.6 \mathrm{~kJ} / \mathrm{kg}$, the ambient air temperature was $28{ }^{\circ} \mathrm{C}$, the relative humidity was $28 \%$ and the specific enthalpy was $45 \mathrm{~kJ} / \mathrm{kg}$. The heater capacity is calculated as $54 \mathrm{~kW}$ using the equation (3).

Cooler capacity account. The coolant capacity is calculated by considering inlet and outlet temperatures with air flow.

$$
Q_{\text {Cooling }}=\dot{m}_{\mathrm{T}} \cdot\left(h_{\mathrm{Ic}}-h_{0 \mathrm{c}}\right)(\mathrm{kW})
$$

The temperature of the mixture entering the cooler was $27.15^{\circ} \mathrm{C}$, the relative humidity was $50 \%$ and the specific enthalpy was $56.1 \mathrm{~kJ} / \mathrm{kg}$, the temperature of the released air was $9.3{ }^{\circ} \mathrm{C}$, The relative humidity was $96.1 \%$ and the specific enthalpy was $27 \mathrm{~kJ} / \mathrm{kg}$. Using the equation (4), the refrigerant capacity is calculated as $85 \mathrm{~kW}$.

Humidifier account. As a humidifier, package type and proportional controlled steam humidifier is preferred. The steam capacity was calculated as $50 \mathrm{~kg} / \mathrm{h}$ from the equation (5), considering the specific humidity values of inlet and outlet with air flow.

$$
N=\frac{\dot{m}_{\mathrm{T}}}{1000} \cdot\left(X_{2}-X_{1}\right)(\mathrm{kg} / \mathrm{h})
$$

\section{Operating room ventilation flow modelling}

Air flow modelling was performed with the parameters calculated in CFD program.

Flow simulations are valid for 0-1 m/s and 0-4 m/s air supply velocity range and are shown in Figure 4 with Figure 5. Accordingly, laminar and low turbulence flow occurs in the laminar flow ceiling outlet and laminar flow ceiling area. 


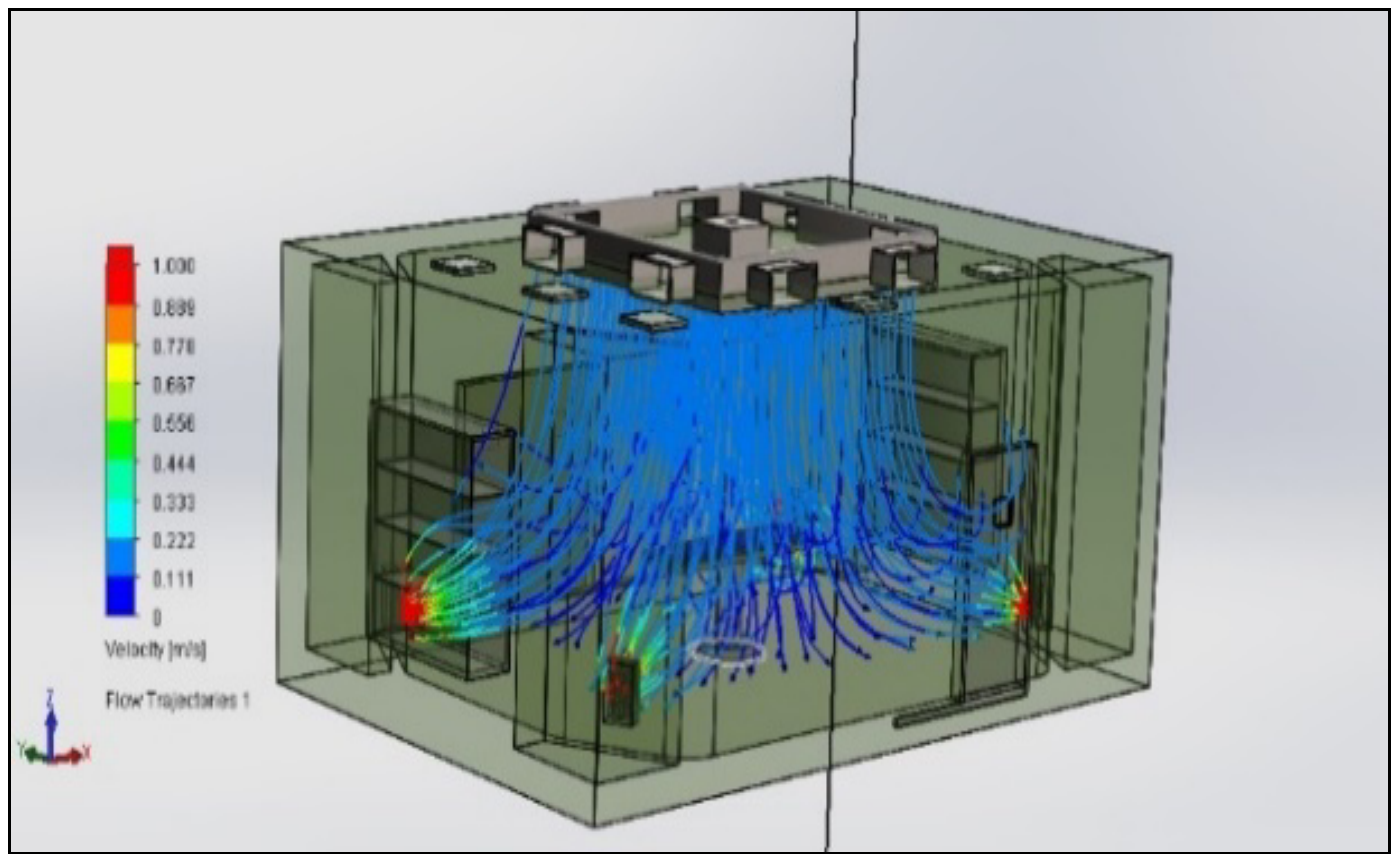

Fig. 4 Air distribution in $0-1 \mathrm{~m} / \mathrm{s}$ air velocity

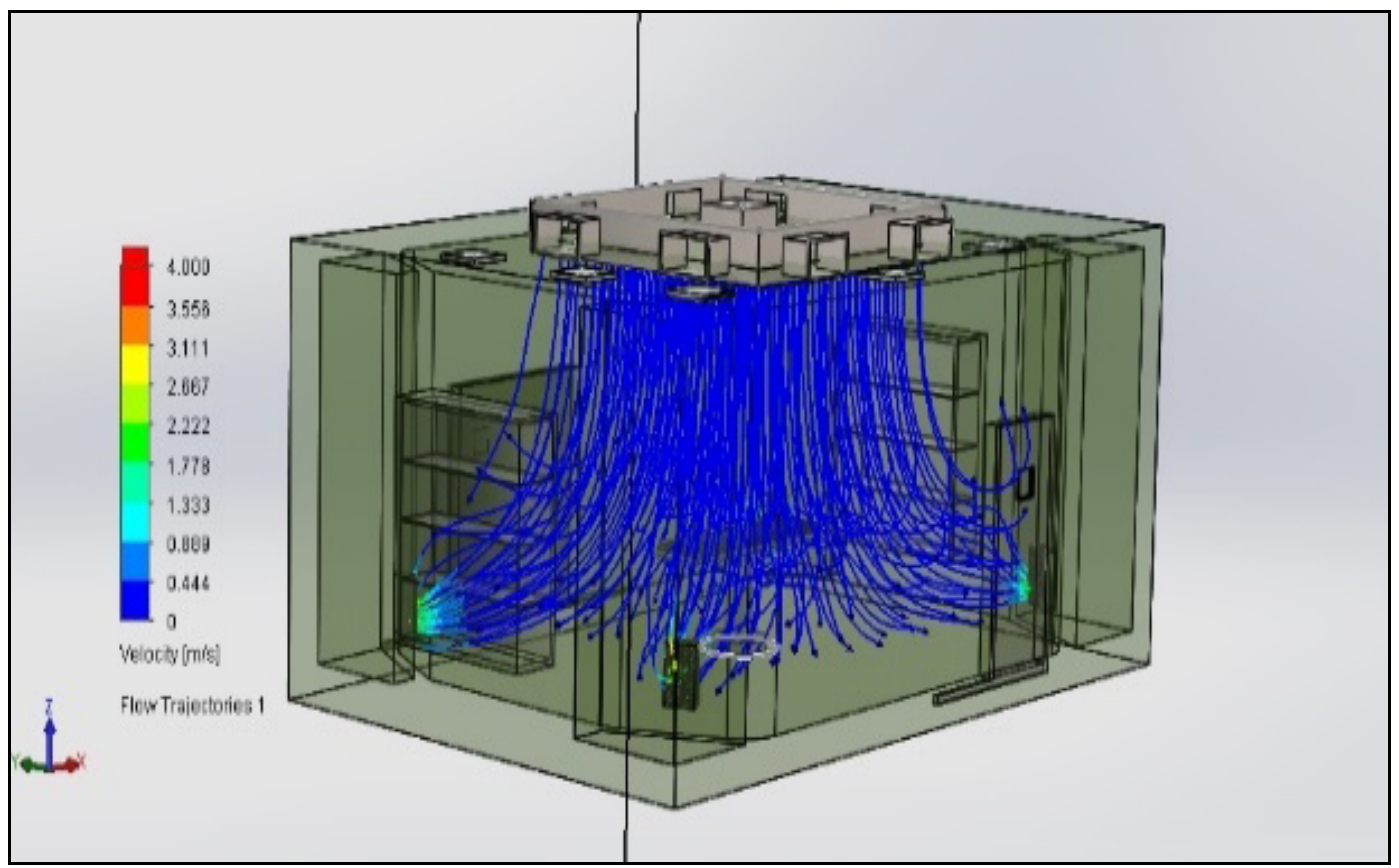

Fig. 5 Air collection at $0-4 \mathrm{~m} / \mathrm{s}$ air velocity

CFD analysis is based on the principle that laminar flow occurs with low-speed fresh air flow from the laminar flow, accelerates with the negative pressure of the fiber-holding suction vents, and removes the particles that may occur during the surgical operation by exhausting them.

\section{Fire and smoke control in the operating room}

In the operating room, according to NFPA 99-6, fire and smoke control was explained in the way $[13,14]$. The air conditioning system inside the operating room is kept at positive pressure according to the volume around the operating room and is operated by providing $100 \%$ fresh air. Since the operating rooms have higher pressure than the adjacent volumes, the 
clean air of the operating room where the fire occurs is closed and only the exhaust is operated and the neighboring volumes are positively compressed, preventing the smoke from the fire from leaking into adjacent volumes. If the air can't be controlled separately for a clean air operation room, it may be necessary to shut down the entire clean air system and continue to run the exhaust air system to prevent smoke from the fire room from splashing into adjacent rooms [8].

\section{Test, cleaning, commissioning and validation of operation room air conditioning system}

In order to operate the air conditioning system efficiently in the operating rooms, the installation is completed in the site first. The sealing tests of the ventilation ducts and the cleaning of the duct by mechanical methods are done [9]. It is determined by measuring the devices according to international standards and the methods prescribed in them and by calibrating them.

\subsection{Air Duct Leakage Tests}

Air duct leakage tests are carried out with a fan with frequency converter, a flow meter with diaphragm, a "duct leakage test device" with manometer unit to measure the duct pressure to ensure test pressure, in order to ensure the test pressure, a fan with frequency converter is manufactured in accordance with SMACNA and DIN24194 standards [8]. Excess leakage in the air ducts will increase operating costs as well as the desired air flow rate in sterile volumes cannot be obtained and the desired pressure balance will not be provided.

\subsection{Duct Cleaning}

Ventilation ducts and system equipment are cleaned at intervals specified according to NADCA standards and according to the methods explained in these standards [17].

\subsection{Disinfection Methods}

Biocide selection and application. The biocide is a common name given to chemicals that help to destroy some living organisms. Biocides are applied only when active mushroom production is suspected or when there is a dangerous level of microorganism pollution as a result of tests after the surface removal of sediments and dirts. The coating application should be sprayed directly to the inner surfaces of the canals rather than misting the surfaces. The coating application is made so as to form a continuous film layer on the surface.

Application of formaldehyde. Formaldehyde is a slightly toxic but very potent antiseptic. It is also used for sterilization of surgical instruments due to its lethal effect on bacteria, fungi and some viruses. Formaldehyde can be applied in HVAC equipment in the form of spraying or mist.

Ozonation. The amount of ozone entering into the HVAC cycle within the desired limits and in time, the organisms that have previously been determined to be resident in the system are destroyed. In addition to its benefits, it has corrosive effects and damages to health.

Use of $U V$ devices. Ultraviolet devices that emit ultraviolet radiation have the effect of destroying living tissues and killing bacteria. The instruments that produce UV rays in quartz can be kept under the influence of the system and prevent the production of germs and bacteria. The AIA and ASHRAE standards predict the use of UV / UVG after the main factor filtering process, [15]. However, it is important to know that the use of UV/UVGI is not the main factor for cleaning the air, it is only used as a way of filtration. 


\subsection{Commissioning and Validation of Hospital Air Conditioning System}

Hospital air conditioning installation after the completion of testing, cleaning and installation of equipment, the system is activated and it is checked whether the project design values are provided [18].

Microbiological control. Depending on the size of the volumes, specific locations identified in the standard are placed in sterile petri dishes, which are special dietary sites. Which of these are the fattening places, the diameter of the petri and so on

HEPA filter. There are two types of tests related to filters, the holding experiments with paraffin oil and the sodium flame tests.

Laminar flow unit. The laminar flow ceiling must be subjected to a leak test at the factory where it was produced before the installation phase. Leakage must be made in accordance with the filter bypass leak test specified in EN 1886. Impermeability tests of the fabricated air conditioner units have been made in accordance with EN 1886 under a pressure of $400 \mathrm{~Pa}$ in laminar flow factory environment. Fig. 6 shows the photograph of the test stand. It has been determined by measuring that the amount of leakage is less than $0.5 \%$ and $0.112 \%$ permitted by international standards.

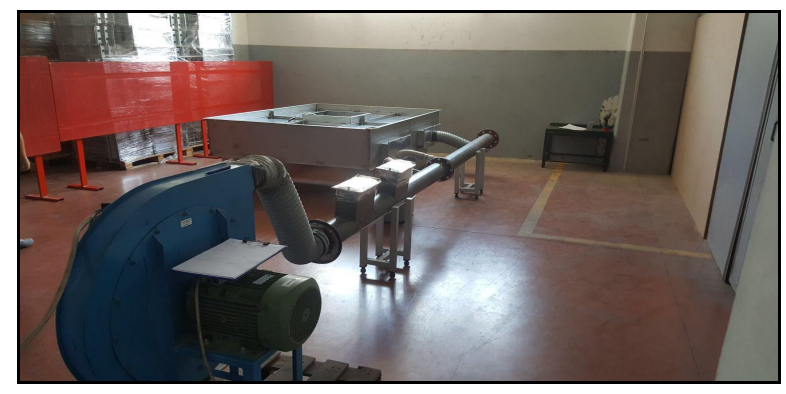

Fig. 6 Laminer flow tightness test

Filters. Check that the filters are placed correctly in the system during assembly. It is proved by testing that the air does not leak around the frame where the filter sits. The difference should be measured before and after the filter against the possibility of filling the filter while the air handling unit is running with the help of pressure measurement sockets. The design pressure losses in the filters used in the hygienic air handling unit and the pressure losses that occurred during the operation have been measured by tests. Measurement results are given in Table 5 as pressure losses.

Table 5 Filter pressure losses

\begin{tabular}{|l|c|c|c|}
\hline Filter Type & G4 & F7 & F9 \\
\hline Design pressure loss $(\mathrm{Pa})$ & 80 & 100 & 120 \\
\hline Measured pressure loss $(\mathrm{Pa})$ & 202 & 87 & 50 \\
\hline
\end{tabular}

Acceptance of the installation requires that the measured pressure loss values are smaller than the values considered for the design. In Table 5, 202 Pa pressure losses measured at filter G4 during operation shows that the filter is dirty and coarse particles with large particles in the air are high.

Necessary measures have been taken for this and it has been concluded that the measured value of the operation has fell below the value specified in the design.

Air handling pressure test. The air that is not filtered in hygienic terms should not leak into the central panel. To control this, the inlet and outlet of the air handling unit are closed. When 
the air handling unit is operated under a certain pressure, the amount of air escaping from the air handling unit body is determined and the air handling unit is divided into surface area.

Battery. Battery capacity is determined by measurements made inside and outside the air handling unit. Checking the installation adequacy should check that the battery is properly installed in the air handling unit and that the air inlet-outlet directions are checked. It should be checked that the installation at the water inlet and outlet locations is correct. In the battery, humidity and temperature measurements should be done on the air side of the battery, and temperature and water flow measurements should be done on the water side. According to these measurements, the actual capacity of the battery is determined.

Air flow measurement and air change rate given to clean room. The measurements are made with a balometer if the grille dimensions are appropriate. If the grills have a large area, the average speed value, or the caravan at the channel port with the CAV, damper, and so on. Air flow can be detected before equipment. For the air flow rate blown from the hygienic air handling unit to the operating room, the necessary traverse points have been determined according to Ashrae Standard 111. At these points, flow rates have been measured with anemometer and the average has been calculated. Measurement results have been given in Table 6. The air flow in the air handling unit has been determined to be $9324 \mathrm{~m}^{3} / \mathrm{h}$ according to the measurements. It has been proved that the air flow rate measured according to the design air flow rate of $8800 \mathrm{~m}^{3} / \mathrm{h}$ is $5.95 \%$ higher, and the air flow rate measured according to the NEBB and ASHRAE standards is within $\pm 10 \%$ of the design air flow rate.

Table 6 Hygienic air handling unit flow measurement

\begin{tabular}{|c|c|c|c|c|c|c|c|}
\hline \multicolumn{2}{|c|}{ Air duct } & \multicolumn{2}{|c|}{ Air flow rate $\left(\mathrm{m}^{3} / \mathrm{h}\right)$} & \multicolumn{2}{|c|}{ Average velocity (m/s) } & \multicolumn{2}{|c|}{ External Static Pressure $(\mathrm{Pa})$} \\
\hline $\begin{array}{l}\text { Measurement } \\
(\mathrm{mm})\end{array}$ & Area $\left(\mathrm{m}^{2}\right)$ & Design & Measured & Design & Measured & Design & Measured \\
\hline $600 \times 500$ & 0.30 & 8800 & 9324 & 8.15 & 8.63 & 1569 & 879 \\
\hline \multirow{5}{*}{\multicolumn{5}{|c|}{ Air speeds at crossmembers $(\mathrm{m} / \mathrm{s})$}} & 7.7 & 8.6 & 9.1 \\
\hline & & & & & 8.3 & 9.1 & 9.9 \\
\hline & & & & & 10.1 & 9.7 & 7.1 \\
\hline & & & & & 9.2 & 8 & 7 \\
\hline & & & & & 8.2 & 9.2 & 8.3 \\
\hline
\end{tabular}

Clean room differential pressure measurement. A test performed during the stage of performance adequacy. One of the tests to be performed for the case where the room is used or not used. The pressure difference between the clean room and the volume connected to the room should be determined.

Clean room particle measurement. If the results of the tests regarding the clean room explained before are positive, particle measurements are taken. Volatile substances of different diameters in the clean room are read and recorded with optical particle readers. With the result values found, the ISO classification number of the hospital clean room according to ISO 14644 standard item 3.2 is determined.

Final inspection studies. All testing and control procedures in hospital clean rooms are documented. The test and control list is prepared and the hospital clean room is delivered to the person responsible for the use. 


\section{Results and evaluation}

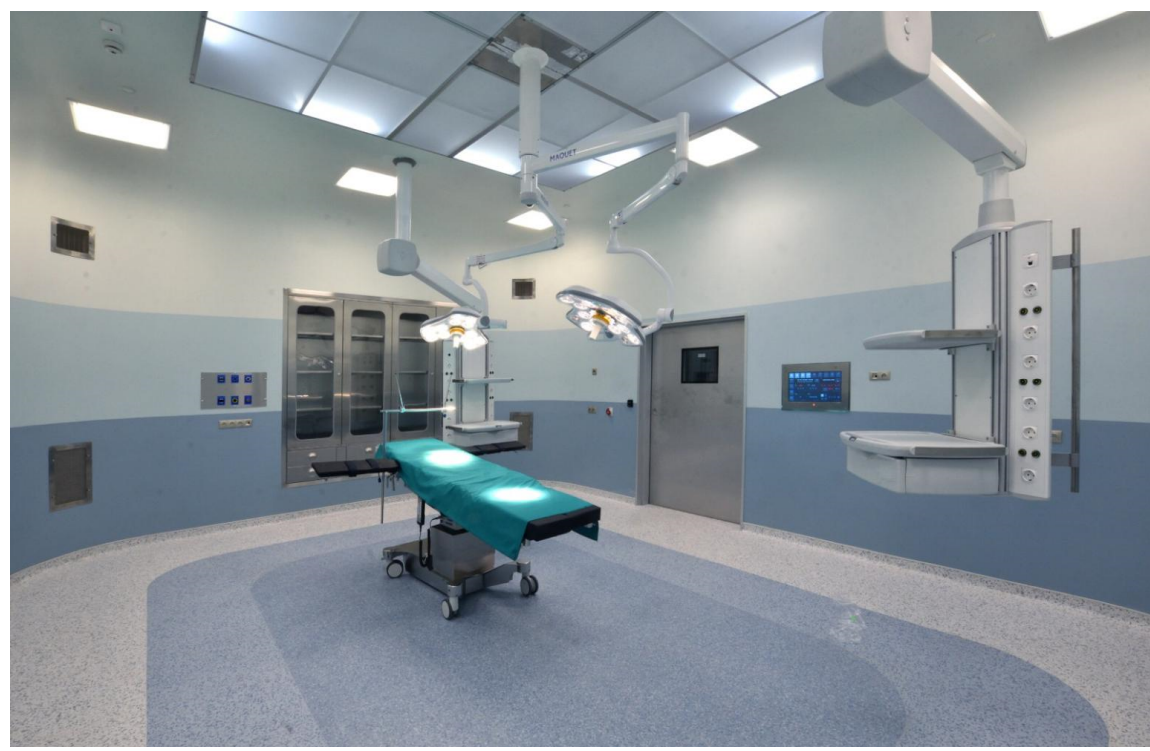

Fig. 7 Hospital Clean Room - Operating Room

In order for the Hygiene Air Conditioning System to operate efficiently, the system equipment during the manufacturing phase has been supplied to EN 1886, such as damper, fire damper, ect. Body sealing classes of the equipment have been selected in accordance with EN 1751 and necessary tightness tests have been carried out. CFD analysis was carried out with the design parameters used for the operating room hygiene air handling unit. Thus, it has been checked that the air distribution in the environment is laminar or low turbulent.

As a result of CFD analysis, operating conditions of laminar flow formation have been determined in order to provide a homogeneous air distribution in the operating room.

Hygienic Air Handling Unit Testing and commissioning of the hygienic air handling unit valid flow, external static pressure, blowing air temperature and humidity etc. parameters have been obtained by measurements according to the measurement methods specified in international standards. The measurement results have been proven to meet the design parameters.

During the first commissioning of the hygiene air handling unit, the filters are clean and the pressure losses have been measured low.

Since the pressure loss will increase in filters due to pollution over time, the air flow rate has been chosen to be $110 \%$ of the minimum air flow rate according to ASHRAE standards.

Determination of the air velocity and the flow rate at laminar flow, operating in the temperature and humidity values, pressurization of environment and microbiologically control of the operating room and particle measurements have been carried out through the Ministry of Health of the Republic of Turkey by specialist teams that have documented operating in accordance with ISO 14644 and opened for service.

In the present study, it is pointed out that the engineering solutions must be produced for saving energy within the standard rules according to the results of the stage of the appropriate projection, manufacturing and measurements. Regaining energy will reduce the annual operating costs. As an example of these engineering solutions, the primary / secondary circuit system in which the preheating and / or cooling of the air is made by using the heat 
from the returning air in the air handling unit that ventilates another room and then sent to the hygienic air handling unit or for the transfer of filtered air between the hygienic spaces recommended in the guide of HTM (Health Technical Memorandum), method of vent transfer can be used.

\section{Conclusion}

When designing a hygienic air handling unit for the operating rooms, which are at the highest level of hygiene and where human health and life are under consideration, it is first determined which surgical interventions to be performed. Accordingly, international standards have been researched and design parameters have been determined. Thus, it has been decided where the air conditioning system would be in the form of multiple systems and where single systems would be. Hygienic air handling unit equipment and duct system have been designed in accordance with the daily usage time and frequency of the volume. In parallel with these processes, it has been clearly demonstrated that architectural building elements will not have a negative impact on the air conditioning system. Quality materials and qualified workmanship, manufacturing and assembly are considered as important elements in order to meet the desired operating conditions of the designed operating room. In order to minimize energy consumption, a system has been designed that uses conditioned and filtered air as much as possible by using heat recovery units, mixing cells and transfer vents as specified in the standards. For the proof that the commissioning and validation process meets the design parameters specified in the project, tightness tests in the air ducts specified in international standards have been carried out in accordance with the duct leakage class. By ensuring that the air leaks are lower than the permitted values, the heated and/or cooled, filtered fresh air has been provided to reach the desired volumes. Thus, operating costs are indirectly reduced. As designer engineers, it is our next expectation to hear that the infections that may occur due to operating room hygiene volumes, air-conditioning installation have decreased and the treatment processes of patients have been shortened. Operating room filter classes and tightness tests and necessary microbiological controls have been performed under the supervision of a hygienist and in coordination. Required parameters are provided for surgical operations with hygiene, air conditioning system in operating rooms. It should be known that this application will cause high energy consumption. However, it should never be forgotten that energy saving can be achieved with smart system applications and human health and life cannot be compared with anything and it is the greatest value.

Nowadays, hospitals are insufficient to meet both today's requirements and medical needs with the developing technology and construction sector. For this reason, either the present clean rooms of the hospitals are renewed with new technology or new hospitals are built. It is aimed to provide an efficient treatment with better quality to more patients with the increased capacity and to provide a continuous service in case of natural disasters such as earthquakes with seismic measurement devices. Hospitals are considered as clean rooms with many sterile environments such as medicine factories, labs and nuclear medical centers. It is well known that the body resistance of people in hospitals is much lower than healthy people. For this reason, infections can occur due to ventilation. Most important case is that in operating rooms where human health is concerned, infections that can happen during and after surgery may extend the treatment process of patients. Surgical infections may also cause the increment of antibiotics usage which will affect the country's economy negatively either. The worst case, it may cause the patient to die. All these dangerous cases have made air conditioning systems the most important subject for Mechanical Engineers. 


\section{REFERENCES}

[1] Divarci, H. Özgüç, Desing Principles of The Hospital Clean Rooms, M.Sc. Thesis, İstanbul Arel University Institude of Science, İstanbul, 2018.

[2] Tuncay Erkan, Minimum airflow and laminate ceiling application for operation rooms, Alarko Carrier Technical Bulletin, Number 36, January 2012

[3] Gürdallar Meftun, Cleaning of HVAC systems in terms of hygiene and indoor air quality, 6. National Plumbing Engineering Congress, October 2003

[4] Gülay Zeynep, Hospital Infections and Their Importance, 8. National Plumbing Engineering Congress, October 2007

[5] Özerdem M.Barış, Mobedi Moghtada, Anil Orkun Baki, Design parameters for air conditioning and ventilation systems for hospital hygienic environments, 8. National Plumbing Engineering Congress, October 2007

[6] Eberliköse Özge, Architectural design of hygienic environments in hospitals, 8. National Plumbing Engineering Congress, October 2007

[7] Kiliç Abdurrahman, Effect of fire measures on internal air quality of hospitals and protection of internal air quality in fires, Tesisat Mühendisliği Dergisi, Number 148 - July / August 2015

[8] DIN 1946-4, VAC Systems in Buildings and Rooms Used in The Health Care Sector, 2008

[9] SMACNA, 'HVAC System Testing, Adjusting \& Balancing', Third Edition, August 2002

[10] VDI 6022 Standard, Hygeienic Standards of Ventilation and Air-Conditioning Systems, 1998

[11] ISO 14644 Standard, Cleanrooms and associated controlled environments, 2015

[12] Republic of Turkey Ministry of Health Construction and Repair Department, Building Minimum Design Guide, 2010

[13] DIN EN 1886 Standard, Ventilation for Buildings Air Handling Units Mechanical Performance, May 1998

[14] NFPA-99, Standard of Health Care Facilities, 2005 Edition

[15] ASHRAE Standard 111, Measurement, Testing, Adjusting, and Balancing of Building HVAC Systems, 2008

[16] AMCA Publication 203-90, Field Performance Measurement of Fan Systems, 2007

[17] The NADCA, Standard for Assessment, Cleaning, and Restoration of HVAC Systems, 2013

[18] NEBB, Procedural Standards For Testing, Adjusting and Balancing of Environmental Systems, Seventh Edition, 2005

Submitted: $\quad 16.9 .2019$

Accepted: $\quad 29.10 .2020$
Prof. Dr.-Ing. Ahmet Can

Istanbul Rumeli University Ins. of Science Faculty of Eng. and Arc., Istanbul, Turkey

Hasan Özgüç Divarci, Mechanical

Engineer MSc.

Science Institut of İstanbul Arel

Üniversity, Istanbul, Turkey

Prof. Dr. Ertan Buyruk

Sivas Cumhuriyet University, Mechanical

Eng. Dept., Sivas, Turkey 